\title{
Regulatory agencies in response to the COVID-19 crisis
}

\section{Sérgio Guerra ${ }^{1}$}

Natasha Schmitt Caccia Salinas ${ }^{1}$

Lucas Thevenard Gomes 1

1 Fundação Getulio Vargas / Escola de Direito do Rio de Janeiro, Rio de Janeiro / RJ - Brazil

This article aims to examine the responses of federal regulatory agencies to the public health crisis - the COVID-19 pandemic. We adhere to the understanding that an empirical evaluation of the patterns of response manifested by the agencies during the pandemic plays an important role in the improvement of public function. First, because it aids the task of adapting regulatory activities more quickly to the needs of the current situation. Secondly, because the context of exceptionality created by the pandemic highlights essential features of the regulatory activity in itself: its conditions of execution and functionalities, limitations and potentialities, and, most of all, its importance for minimizing losses in scenarios of structural instability. The data used in this study was gathered from the Official Gazette Diário Oficial da União (DOU) and the websites of the eleven regulatory federal agencies. In our analysis, we only selected measures with an impact on the regulated sector. We found significant heterogeneity in the number of agency responses, partly related to sectorial differences, but mostly arising from asymmetries of institutional capability among these bodies. We also found heterogeneity of content in the responses given by agencies to similar regulatory problems, which suggests the existence of failures in regulatory coordination in urgent need of a solution.

Keywords: COVID-19; regulatory agencies; emergency regulations; institutional capacity; regulatory coordination.

\section{As agências reguladoras em resposta à crise da COVID-19}

Este artigo tem por objetivo analisar as respostas das agências reguladoras federais para o enfrentamento da crise de saúde pública gerada pelo novo coronavírus. Parte-se do entendimento de que a avaliação empírica dos padrões de resposta evidenciados pelas agências durante a crise da COVID-19 cumpre um papel importante no aprimoramento da função pública. Em primeiro lugar, porque oferece subsídios para que a própria atividade regulatória se adapte de forma mais célere às necessidades do atual momento de crise. Em segundo, porque o contexto excepcional gerado pela pandemia coloca em evidência alguns traços essenciais da atividade regulatória: suas condições de exercício e funcionalidades, suas limitações e potencialidades e, sobretudo, sua importância para a minimização de danos em cenários marcados por instabilidade estrutural. Os dados utilizados no presente estudo foram extraídos do Diário Oficial da União (DOU) e dos sítios eletrônicos das 11 agências reguladoras federais. Para a presente análise, foram selecionadas apenas as medidas com efetivo impacto regulatório sobre o setor regulado. Identificamos uma significativa heterogeneidade no volume de respostas das agências, em parte relacionada a diferenças setoriais, mas sobretudo decorrente de assimetrias na capacidade institucional desses órgãos. Identificamos também uma heterogeneidade no conteúdo das respostas das agências a problemas regulatórios semelhantes, evidenciando falhas de coordenação regulatória que precisam ser urgentemente solucionadas.

Palavras-chave: COVID-19; agências reguladoras; medidas regulatórias emergenciais; capacidade institucional; coordenação regulatória. 


\section{Las agencias reguladoras en respuesta a la crisis de la COVID-19}

El objetivo de este artículo es analizar las respuestas de las agencias reguladoras federales para enfrentar la crisis de salud pública creada por el coronavirus. Entendemos que la evaluación empírica de los protocolos de respuesta llevados a cabo por las agencias durante la crisis de la COVID-19 cumple un papel importante para perfeccionar la función pública. En primer lugar, porque ofrece subsidios para que la propia actividad regulatoria se adapte de forma más rápida a las necesidades del momento actual de la crisis. En segundo lugar, porque el contexto excepcional producido por la pandemia pone en evidencia algunos rasgos esenciales de la actividad regulatoria: sus condiciones de ejercicio y operaciones, sus limitaciones y potencialidades y, sobre todo, su importancia para la minimización de daños en momentos de inestabilidad estructural. Los datos utilizados en el presente estudio provienen del Diário Oficial da União (DOU), así como de los sitios web de las once agencias reguladoras federales. Hemos seleccionado para este análisis solamente las medidas de impacto regulatorio efectivo sobre el sector regulado. Identificamos una heterogeneidad significativa en el volumen de respuestas de las agencias, que se relaciona, en parte, con diferentes sectores, pero cuya causa principal resulta las asimetrías de capacidad institucional entre los órganos. Identificamos también una heterogeneidad de contenido en las respuestas de las agencias ante algunos problemas regulatorios semejantes, lo que demuestra deficiencias en la coordinación regulatoria que se necesitan solucionar urgentemente.

Palabras clave: COVID-19; agencias reguladoras; medidas regulatorias de emergencia; capacidad institucional; coordinación regulatoria.

\section{INTRODUCTION}

With the aggravation of COVID-19 crisis, regulatory agencies have responded to new demands from society, regulated economic agents and other federal government bodies and entities.

Before the pandemic, regulatory agencies had been adopting measures to comply with new legislative and executive requirements on regulatory decision-making processes (Salinas \& Brelaz, 2020). The legislative power had recently required agencies to include notice-and-comment and regulatory impact analysis in their rulemaking processes (Statute No 13,848, 2019). The executive power forced agencies to act more efficiently by setting deadlines to their most relevant decisions (Statute No 13,874, 2019). This same body adopted measures which directly affected agencies' regulatory agendas, as the determination for reviewing red tape regulations (Presidential Order No 10,139, 2019).

Besides undertaking these new roles, regulatory agencies kept on performing their typical regulatory functions such as issuing rules, inspecting regulated actors, imposing sanctions and solving conflicts (Marques, 2003). However, the new coronavirus crisis forced agencies to replace part of their regular activities with more urgent responses to a new scenario of risks and uncertainty.

Health and sanitary regulatory agencies, directly affected by the pandemic, were encouraged to offer solutions to prevent and treat the disease. Agencies that regulate public utilities such as transportation, telecommunications, power supply and gas distribution took measures to ensure that these services would not be suspended despite demand declines. Regulatory agencies were also called upon to moderate conflicting interests between regulated economic agents and customers. Service demand declines and customers' delinquency affect the solvency of service providers affect the solvency of 
service providers in such a way as to make regulatory measures necessary to ensure the regularity of service provision and the protection of contractual rights and obligations.

In this context of urgency, planned regulatory actions (Coglianese \& Walters, 2016) are replace by emergency measures; instead of rational (Baldwin, Cave, \& Lodge, 2012) and participative (Kerwin \& Furlong, 2018) regulatory processes, pragmatic decisions arise. Procedural requirements are suspended, extinct or extended, so that agencies can focus on confronting the pandemic. Similarly, contractual obligations imposed on regulated agents are replaced by more negotiated agreements and terms.

The main objective of this article is to examine the responses of federal regulatory agencies to the public health crisis - the COVID-19 pandemic. We adhere to the understanding that an empirical evaluation of the patterns of response manifested by the agencies during the pandemic plays an important role in the improvement of public function. First, because it aids the task of adapting regulatory activities more quickly to the needs of the current situation. Secondly, because the context of exceptionality created by the pandemic highlights essential features of the regulatory activity in itself: its conditions of execution and functionalities, limitations and potentialities, and, most of all, its importance for minimizing losses in scenarios of structural instability.

With these objectives in mind, in the first part of this article we measure the responses offered by regulatory agencies to the pandemic. In the second part we divide these measures into categories and describe them. In the last part, we analyze the limits and possibilities of agencies' responses in dealing with the direct and indirect effects of the COVID-19 pandemic.

\section{MEASURING REGULATORY RESPONSES}

In order to assess the behavior of regulatory agencies during the crisis, we built a database with measures adopted by federal agencies in response to the new coronavirus epidemic. We collected data from the websites of eleven federal regulatory agencies and from the Official Gazette (Diário Oficial da União [DOU]). The database comprises regulations and administrative decisions - such as technical notes, secondary orders, circular letters - with an effective impact on the regulated sector. We excluded from this study measures about agencies' internal affairs or personnel management - which may, for example entail rules for telecommuting, virtual meetings, among others.

Four months after the World Health Organization announced the pandemic, 307 emergency measures were adopted by federal regulatory agencies. ${ }^{1}$ Graph 1 and 2 shows the historical evolution of these measures throughout time. Measures began to intensify in March, especially in the week beginning 16th March 2020. A larger number of measures were undertaken in the months of March and April.

${ }^{1}$ This study's time limit is June 30th, 2020. 


\section{GRAPH 1 MEASURES IN RESPONSE TO COVID-19 BY MONTH}

\section{Monthly Evolution}

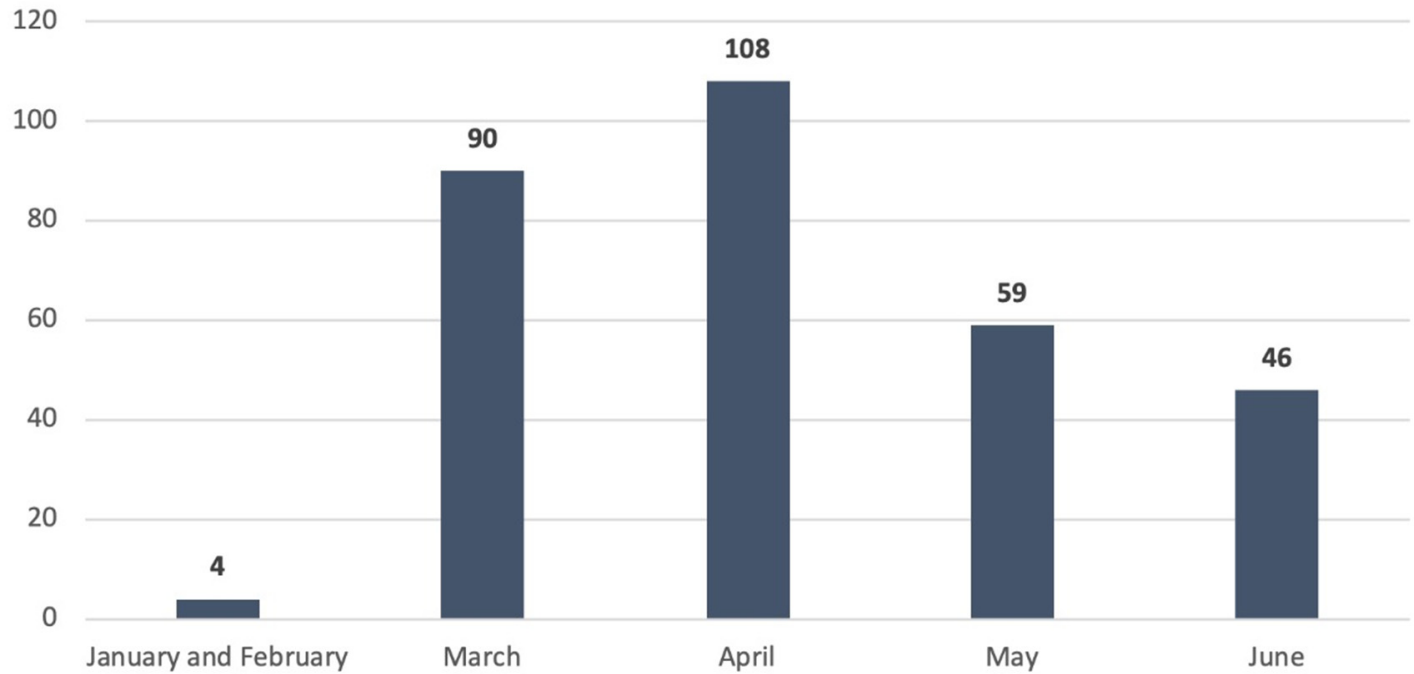

Source: Elaborated by the authors.

GRAPH 2 MEASURES IN RESPONSE TO COVID-19 BY AGENCY

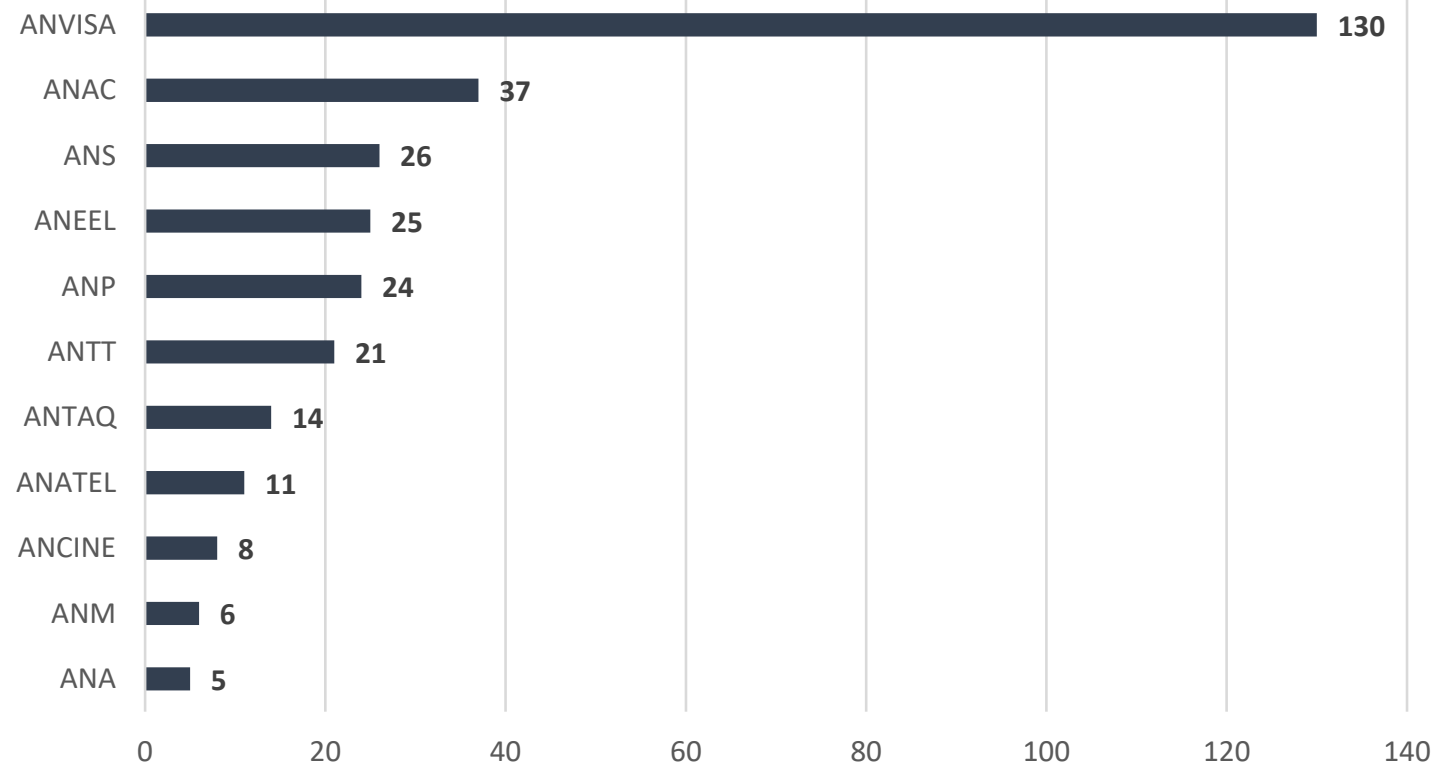

Source: Elaborated by the authors. 
Virtually all regulatory agencies offered some kind of response to the pandemic crisis. The responses herein analyzed reveal that COVID-19 pandemic has had a major impact on regulated sectors. As mentioned above, we excluded from this study measures that only affect agencies' internal affairs, like telecommuting or personnel management rules.

The National Agency for Sanitary Surveillance (Agência Nacional de Vigilância Sanitária [ANVISA]) outstands as the body that adopted the higher number of measures in response to COVID-19. This is unsurprising due to the nature of ANVISA's authority. As it will be discussed in the next section, ANVISA offered expeditious responses to the crisis. In addition, ANVISA's measures guided not only the behavior of regulated agents, but also the actions of various federal government institutions, including other regulatory agencies. Graph 3 shows the evolution of mentions to COVID-19 or Coronavirus in the Official Gazette.

\section{GRAPH 3 MENTIONS TO COVID-19 OR CORONAVIRUS IN THE OFFICIAL GAZETTE}

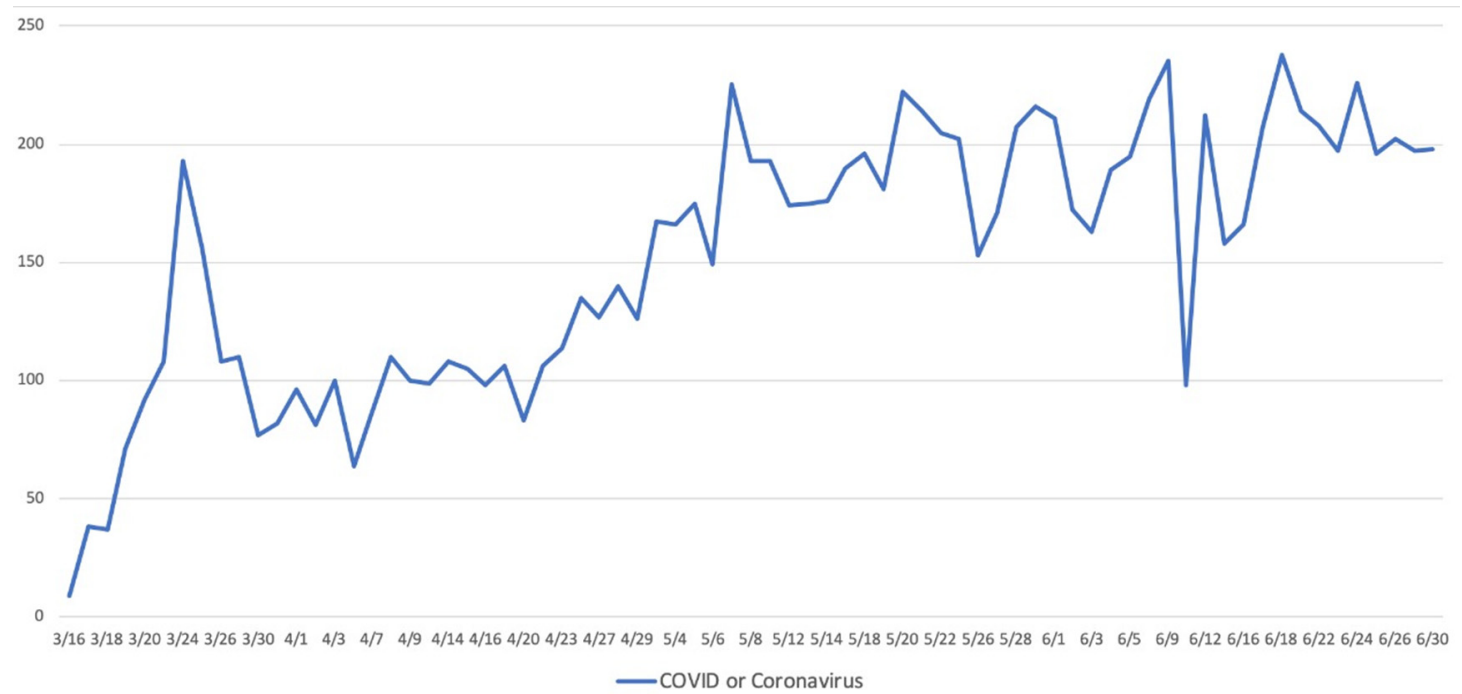

Source: Elaborated by the authors.

We also measured the number of COVID-19 press releases on agency websites as of March 9th. ${ }^{2}$ The National Agency of Supplementary Health (Agência Nacional de Saúde Suplementar [ANS]), the National Civil Aviation Agency (Agência Nacional de Aviação Civil [ANAC]) and ANVISA issued the hignest numbers of COVID-19 releases. Perhaps not coincidentally, these three agencies also adopted the higher number of measures against COVID-19.

${ }^{2}$ We only considered releases which expressly mentioned the words COVID-19 or coronavirus. 


\section{GRAPH 4 COVID-19 PRESS RELEASES ON AGENCIES WEBSITES}

- Mention to COVID-19 a Other
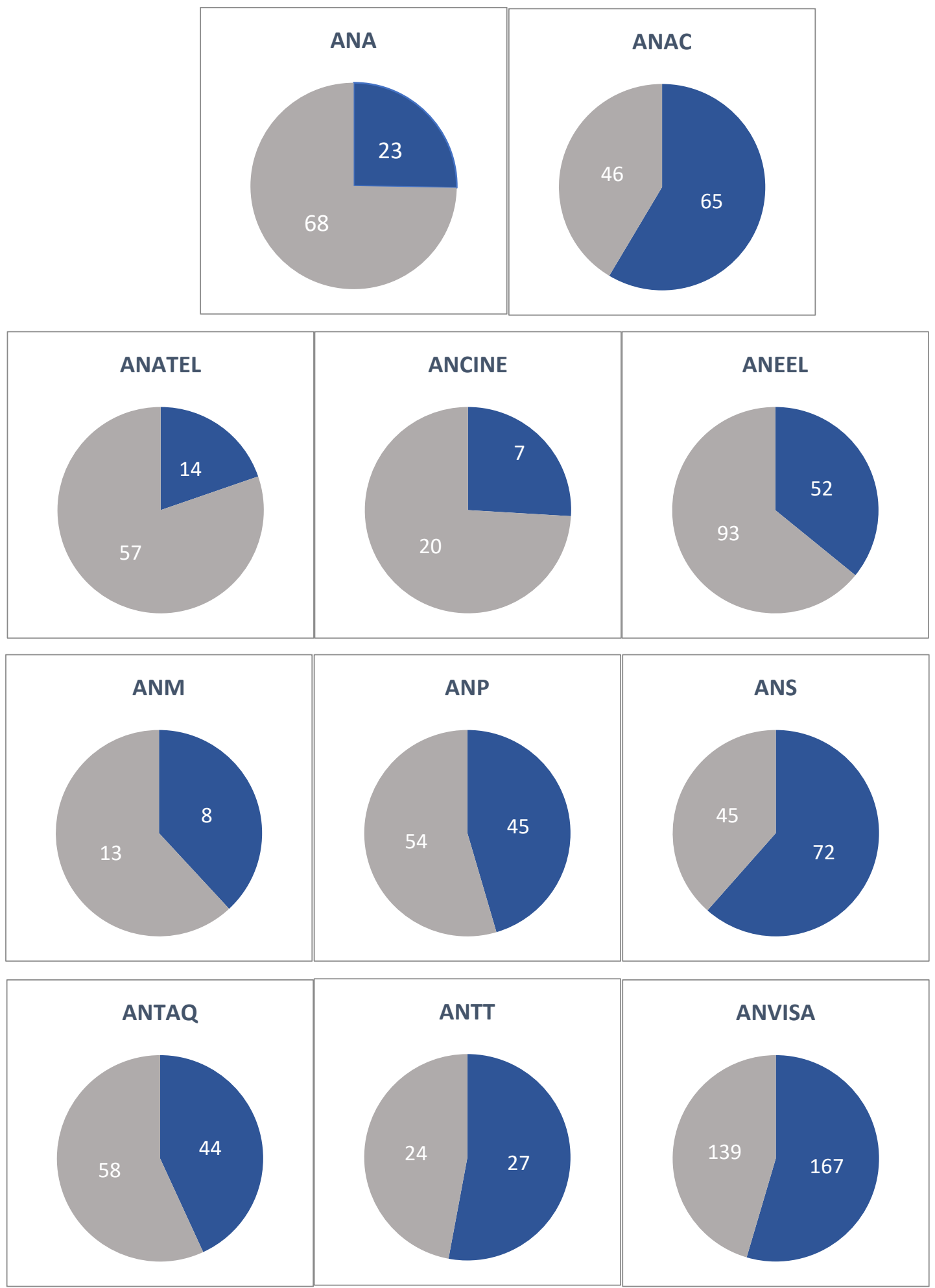

Source: Elaborated by the authors. 
The next section analyzes the content of agencies' responses to the COVID-19 pandemic.

\section{AGENCIES’ RESPONSES TO COVID-19}

Agencies' responses to COVID-19 fall into three different categories. First, agencies may relax some of its own functions and obligations to face the pandemic. Second, some agencies act directly to prevent the virus' transmission or to treat the disease. Third, some agencies adopt measures to ensure the provision of utilities and services under abnormal circumstances. This last line of action can be further divided into three sets of measures: relaxation of service provision conditions; economic support to regulated agents; and protection of service's users rights.

The next subsections are divided into these categories and describe in details agencies' responses to COVID-19. These categories are non-excluding, which means that a single measure might have more than one objective and in this case it will be classified in more than on category. ${ }^{3}$

\subsection{Relaxation of agencies' functions}

We begin by analyzing relaxing measures on agencies ordinary functions. ${ }^{4}$ The Graph 5 presents the number of relaxing responses adopted by each agency.

\section{GRAPH 5 RELAXATION MEASURES ON AGENCIES FUNCTIONS}

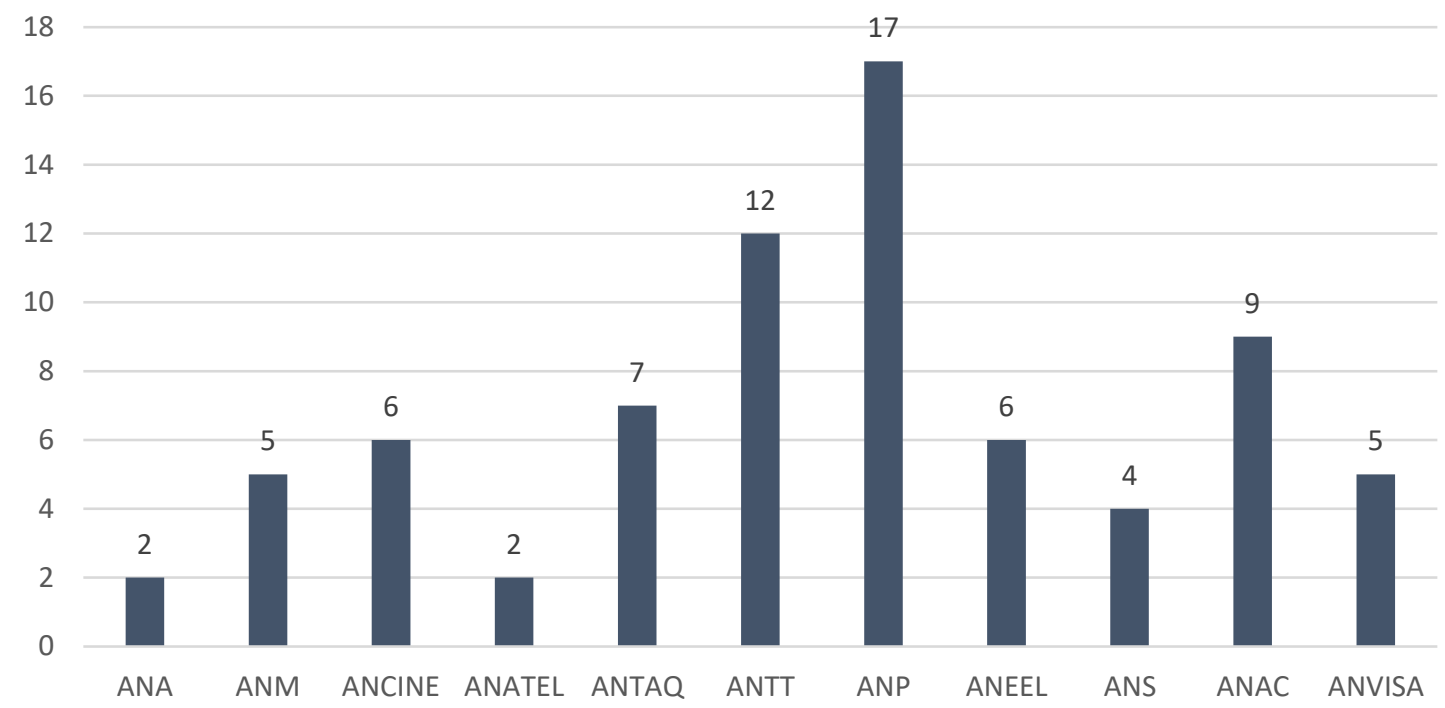

Source: Elaborated by the authors.

\footnotetext{
${ }^{3}$ Since the categories listed above are non-excluding, the sum of actions showed in graphs 5-8 will be different from the sum of measures showed in graph 1.

${ }^{4}$ As already mentioned, we excluded from this study measures concerning agencies internal affairs. When we thus refer to relaxing measures on agencies' functions, we mean actions that have a direct impact on regulated agents (e.g., relaxation of procedural deadlines).
} 
A large number of measures adopted by agencies are not directed at confronting the pandemic. In several cases, coronavirus is presented as the background for adopting measures to respond to indirect effects of the crisis. For example, the COVID-19 pandemic has forced agencies to relax or event interrupt some of their regulatory functions, including procedural obligations and audits and inspections.

Agencies have been compromising some of their typical regulatory functions in order to face the pandemic's impacts. Social isolation and lock down determinations turn relaxation measures inevitable.

Most agencies, for example, delayed the issuance of permits, certificates, authorizations and licenses for activities unrelated to the pandemic.

The Brazilian National Agency for Petroleum, Natural Gas and Biofuels (Agência Nacional de Petróleo, Gás Natural e Biocombustíveis [ANP]) postponed events and notice-and-comment procedures; suspended inspections (Resolution No 812, 2020), hearings and auctions; postponed deadlines to issue certificates and sign agreements. The National Land Transportation Agency (Agência Nacional de Transportes Terrestres [ANTT]) postponed inspections (Administrative Rule No 102, 2020; Administrative Rule No 117, 2020), extended contractual deadlines (Resolution No $5,979,2020$ ), interrupted ongoing adjudications (Resolution No 5,878, 2020) and replaced in person meetings and hearings with online sessions (Resolution No 5,891, 2020).

The National Civil Aviation Agency (Agência Nacional de Aviação Civil [ANAC]) extended the duration of certificates, authorizations, registrations, as well as trainings and tests requirements for airline pilots. It also suspended, for indeterminate time, entrance exams for pilots, maintenance operators, flight attendants and air traffic controllers, and authorized the National Aviation Training Center to promote online training courses for civil aviation careers. The National Waterway Transportation Agency (Agência Nacional de Transportes Aquaviários [ANTAQ]) cancelled an auction and suspended or postponed procedural deadlines (Administrative Rule No 109, 2020; Resolution No 7,784, 2020).

ANVISA delayed the issuance of permits and authorizations for activities unrelated to the pandemic (Resolution No 355, 2020), whereas the National Electricity Regulatory Agency (Agência Nacional de Energia Elétrica [ANEEL]) postponed administrative procedures diligences (Administrative Rule No $6,310,2020$ ) and postponed several auctions (Administrative Rule 134, 2020). The National Mining Agency (Agência Nacional de Mineração [ANM]) postponed several procedural deadlines and the National Agency of Telecommunications (Agência Nacional de Telecomunicações [ANATEL]) relaxed accreditation procedures. The National Film Agency (Agência Nacional do Cinema [ANCINE]) suspended temporarily deadlines for filing reports on audiovisual projects (Administrative Rule No 151-E, 2020), while the National Water Agency (Agência Nacional de Águas [ANA]) extended the duration of water use permits (Resolution No 21, 2020).

To some agencies, these relaxation measures had a positive side effect, bringing more efficiency to their work. ANVISA (2020) became faster in issuing authorizations for the production, import and distribution of medicines, pharmaceutical products and medical equipment. ANA (2020) was able to respond to a larger number of water use requests. ANEEL (2020) decreased maintenance costs and increased staff productivity with telecommuting. 


\subsection{Confronting measures to COVID-19}

Some agencies also adopted measures to confront COVID-19 directly.

\section{GRAPH 6 MEASURES TO CONFRONT THE PANDEMIC}

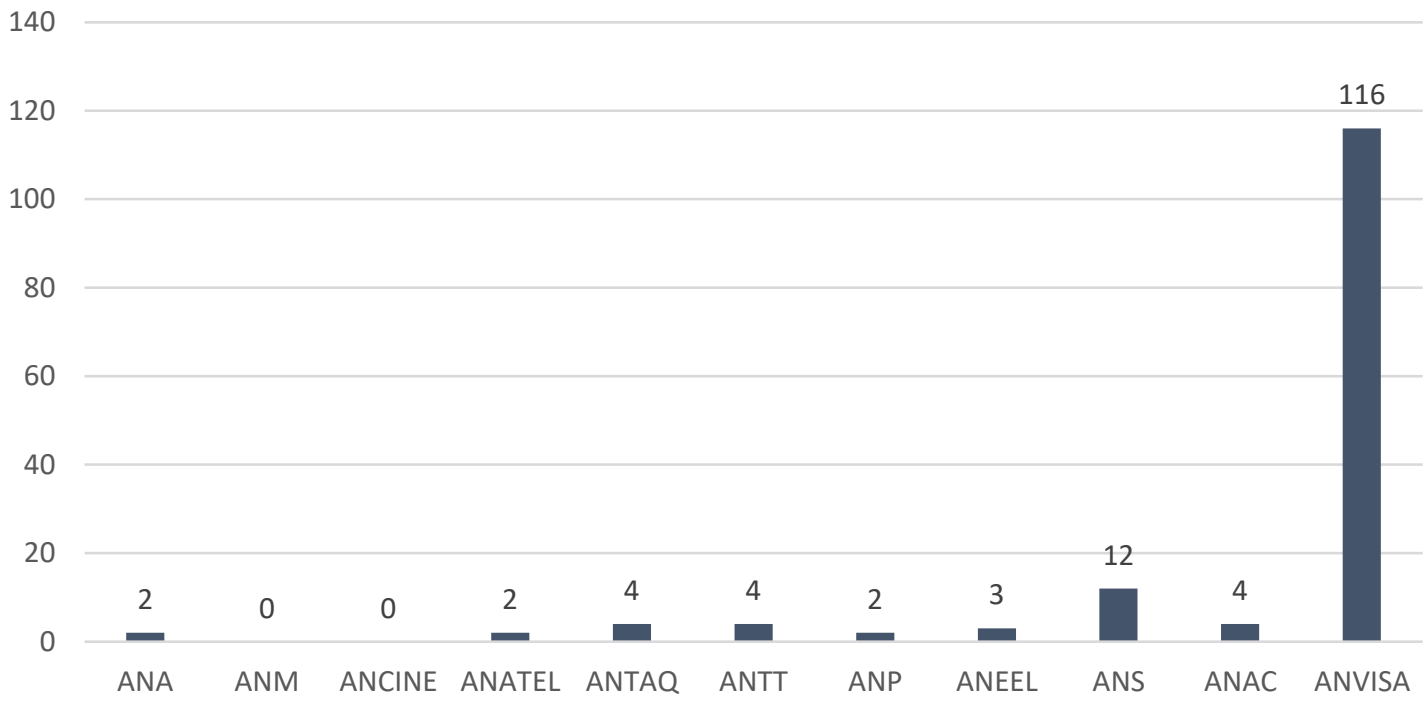

Source: Elaborated by the authors.

ANVISA is by far the most active agency on facing the coronavirus pandemic. We identified 149 confronting measures, 116 of which $(77,8 \%)$ were adopted by this regulatory agency.

ANVISA's measures comprised a wide range of subjects, including: standards for manufacturing and distributing medicines to treat the disease; manufacturing, importing and commercialization controls for medical devices needed for treating patients hospitalized with coronavirus; sanitary control in ports, airports and land borders; manufacturing standards for disinfecting products (e.g., 70\% alcohol hand sanitizer); technical criteria for conducting coronavirus tests in blood, cells, tissues and organs; guidelines for conducting clinic essays and experiments for treating the disease; ${ }^{5}$ vaccination measures against influenza during the pandemic; measures against contamination with COVID-19 virus in elderly care institutions.

Due to its regulatory scope, ANVISA played a leading role in confronting the pandemic. Sanitary surveillance is key for preventing contamination with COVID-19 virus.

Agencies that deal well with crisis situations show an ability to anticipate problems and to offer efficient responses (Matthews, 2012). Several weeks before community transmission of the new

${ }^{5}$ For example, ANVISA authorized the experimental use of sulfate of hydroxychloroquine/azithromycin di-hydrated (Special Resolution No 922, 2020). 
coronavirus was detected in Brazil, ANVISA created an emergency group through Administrative Rule No 74 (2020) with the aim of monitoring and confronting the disease in the country. ANVISA had been undertaken measures to confront COVID-19 well before the disease became a serious threat to the national public health and well before other agencies started to take similar actions (Croda \& Garcia, 2020). Thus, when the COVID-19 crisis emerged, ANVISA had already developed a "critical thinking" to deal with its major impacts.

ANVISA is also tuned to international regulatory practices and foreign research (Pereira, 2014). When the Brazilian government formally asked China and other countries for help in confronting the disease, ANVISA had already exchanged knowledge and information with these same countries.

Besides ANVISA, The National Agency of Supplementary Health (Agência Nacional de Saúde Suplementar [ANS]) adopted measures to confront the pandemic. Important measures were Normative Resolution No 453 (2020) and Normative Resolution No 458 (2020), which obligated health insurance companies to cover the costs of COVID-19 tests and treatments.

ANS adopted measures to encourage virtual healthcare. Telemedicine services had been regulated since 2002 by the Federal Medical Board (Conselho Federal de Medicina [CFM]) (Resolution No 1,643, 2002). On March $19^{\text {th }}$, CFM sent an official letter to the Health Department positioning itself in favor of telemedicine through remote consultation, monitoring and guidance. Following this measure, the President issued the Administrative Rule No 467 (2020) on telemedicine and Congress passed Statute No 13,989 (2020), which authorized the practice of telemedicine during the crisis.

Simultaneously, the National Boards of Psychiatry, Speech-language Pathology and Audiology, Nutrition, Physiotherapy and Occupational Therapy issued their own rules providing for telehealth services. ANS adopted measures to require the coverage of telehealth services even if they were not mentioned in contracts between health insurance companies and health service providers.

Transportation regulatory agencies also adopted confronting measures to the COVID-19. Especially ANAC and ANTT relaxed rules for transportation of infected passengers, pharmaceutical products, medicines and medical equipment through air taxis (Administrative Rule No 880, 2020), aircrafts with patient's isolation units (Decision No 83,2020) and helicopters (Resolution No 559,2020).

ANTT relaxed, through Resolution No 5,875 (2020), safety rules for the transportation of fractioned ethanol or $70 \%$ ethanol solution. The rules for the transportation of this key sanitizing product is much stricter in regular circumstances.

ANVISA and transportation agencies have worked in collaboration to make the transport of hazard products and contaminated passengers possible. On one hand, ANVISA's sanitary rules were quintessential to prevent passengers from contamination in ports, airports and railroads. On the other hand, ANVISA benefited from the relaxation of transport rules issued by ANAC and ANTT. 
In a smaller scale, three other agencies took initiatives to confront the pandemic. The National Agency of Telecommunications (Agência Nacional de Telecomunicações [ANATEL]) authorized the creation of a telephone number (1960) for assisting patients in need of emergency treatment against COVID-19. This agency was also part of a network coordinated by the Science and Technology Department in charge of making internet available to all health service units (Administrative Rule No 1,153, 2020). The National Water Agency (Agência Nacional de Águas [ANA]) created through Administrative Rule No 165 (2020) a committee in charge of coordinating a pilot project for monitoring COVID-19 virus in sewage plants. This project has been undertaken by Minas Gerais Water Management Institute (Instituto Mineiro de Gestão de Águas [IGAM]) and the National Institute of Science and Technology on Sustainable Sewage Treatment Plants (Instituto Nacional de Ciência e Tecnologia/Estações de Tratamento Sustentáveis [INCT/ETEs] Sustentáveis), the latter belonging to the Federal University of Minas Gerais (Universidade Federal de Minas Gerais [UFMG]). The project detects COVID-19 virus in the wastewater effluents of Belo Horizonte and Contagem rivers, serving as a method to detect levels of contamination in the region. Finally, the National Electricity Regulatory Agency (Agência Nacional de Energia Elétrica [ANEEL]) approved energetic efficiency projects in Bahia and Pernambuco hospitals.

For confronting the pandemic, regulatory agencies have also been implementing measures which are determined by other public administrative bodies. For example, transportation agencies follow presidential orders to shut down immigration services in ports, airport and land borders. ${ }^{6}$ ANVISA plays a key advisory role in the drafting of these orders.

\subsection{Measures to ensure regularity of service provision}

Regulatory agencies play a key role in ensuring proper provision of services such as electricity distribution, telecommunications, and sewage treatment. Statutes and regulations establish the conditions for service provision. Statute No 8,987, 1995, which governs public services concessions, determines that an adequate service must meet the standards of "regularity, consistency, efficiency, security, modernity, generality, courtesy and affordability". It is the role of regulatory agencies to issue their own regulations to implement these statutory standards.

In regular circumstances, all service provision standards must coexist in harmony. It is insufficient that a service is provided regularly. It must also be provided with a reasonable price and by using the best technology available.

In the context of a pandemic, however, regulatory agencies are forced to relax standards of service provision in order to ensure its regularity. In such adverse circumstances, it has become more important to ensure regularity rather than quality in service provision.

\footnotetext{
${ }^{6}$ For example, a Joint Administrative Rule No 152 (2020), signed by the President's Cabinet Office, the Justice and Public Security Department, the Infrastructure Department and the Health Department, banned the entry of non-resident foreigners through airports. Administrative Rule No 47 (2020) banned the disembarking of non-resident foreigners at Brazilian ports.
} 
To ensure that public services are not suspended during the pandemic, virtually all agencies were forced to relax standards for service provision. In this way we observed two main strategies adopted by agencies to ensure regularity of service provision. For services with declining demands, agencies adopted measures to alleviate the financial burdens of service providers. In a smaller scale, agencies also offered some king of financial support to economically vulnerable consumers who could not afford to pay for these services during the pandemic.

\subsubsection{Relaxation of Service Provision Standards and Economic Activities Requirements}

The pandemic turned the relaxation of service provision standards and economic activities requirements inevitable. Graph 7 shows measures of this kind adopted by agency.

\section{GRAPH 7 RELAXATION OF SERVICES AND ECONOMIC ACTIVITIES}

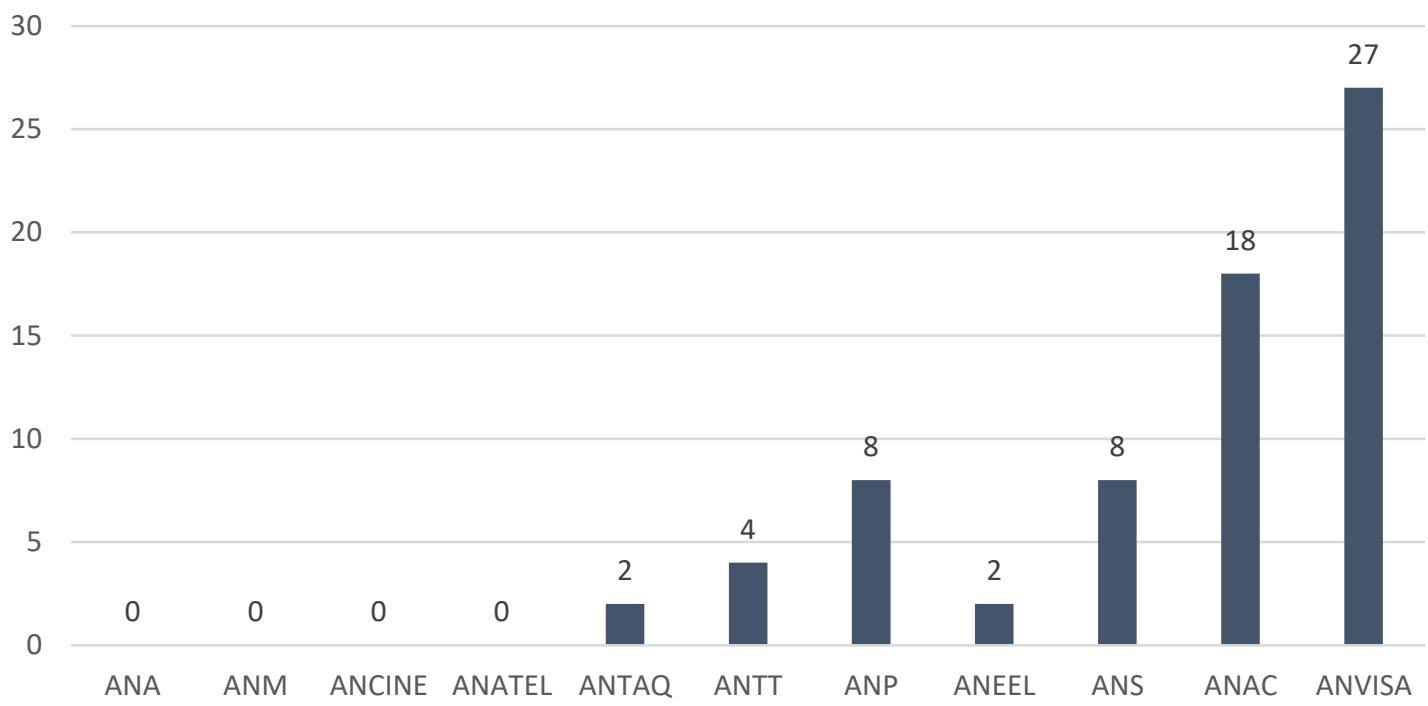

Source: Elaborated by the authors.

ANVISA relaxed accreditation and authorization requirements for the production, importation and distribution of medicines, pharmaceutical products and medical equipment. This agency authorized various companies and institutions to manufacture and distribute $70 \%$ alcohol hand sanitizers (Resolution No 347, 2020, and Resolution No 350, 2020), exempted from registration medical devices needed for treating patients hospitalized with coronavirus (Resolution No 356, 2020), authorized public agricultural labs to perform COVID-19 diagnostics (Resolution No 364, 2002), authorized the importation of devices needed in intensive care units, among others.

In the transportation sector, some services were effectively suspended, such as international road transport of passengers (Resolution ANTT No 5.875, 2020) and recreational waterway transportation. 
(Resolution ANTAQ No 7.653, 2020). Some state and local governments banned interstate road transport of passengers. These state and local decisions did not have the support of The National Land Transportation Agency (Agência Nacional de Transportes Terrestres [ANTT]), which is against the suspension of transport services. ${ }^{7}$

However, the great majority of services kept being provided, sometimes with lower standards. For example, civil aviation service was reduced to less than $10 \%$ of its capacity. ${ }^{8}$ The National Civil Aviation Agency (Agência Nacional de Aviação Civil [ANAC]) created an alternative route network to maintain all parts of the country interconnected during the pandemic. ANAC also relaxed the rules for changing flight itineraries and times. It also exempted airlines from assisting passengers when a flight was delayed or cancelled due to external factors (Resolution No 556, 2020). ANTT allowed companies to make changes and cancellations in road transportation roots (Resolution No 5,875 (2020) and ANTAQ reduced waterway transportation to 50\% of its capacity.

ANS authorized health insurance companies to delay elective or non-urgent consultations, exams, therapies and surgeries (Resolution No 259, 2011). It also suspended the coverage of hospital-day regime $^{9}$ and elective hospitalizations. As previously mentioned, the agency also encouraged health insurance companies to cover telehealth services.

Similarly, ANEEL exempted electricity providers from attending costumers in person, sending printed monthly bills, conducting on-sight inspections at consuming units and so forth (Resolution No 878, 2020).

ANP exempted oil distributors from holding minimum levels of oil stocks (Resolution No 812, 2020), and authorized companies to burn daily rates of natural gas on small productions fields (Resolution No 816, 2020).

\subsubsection{Financial Support to Regulated Agents}

Some regulatory agencies have also provided economic and financial support to regulated agents in order to ensure regularity of services provisions. Graph 8 shows financial support measures adopted by each agency.

\footnotetext{
${ }^{7}$ The National Transport Confederation (Confederação Nacional do Transporte [CNT]) filed a lawsuit before the Brazilian Supreme Court (Supremo Tribunal Federal - STF), the Arguição de Descumprimento de Preceito Fundamental (ADPF) No 665, with the aim of annulling these state and local orders. ANTT filed a petition arguing for the unconstitutionality of these measures.

${ }^{8}$ In April, the number of weekly flights dropped from 14,781 to 1,241.

${ }^{9} \mathrm{~A}$ hospital-day regime is the intermediary assistance between hospitalization and laboratory care for the realization of clinical, surgical, diagnostic and therapeutic procedures. For this attendance, the patient stays at the hospital for approximately 12 hours.
} 


\section{GRAPH 8 FINANCIAL SUPPORT TO REGULATED AGENTS}

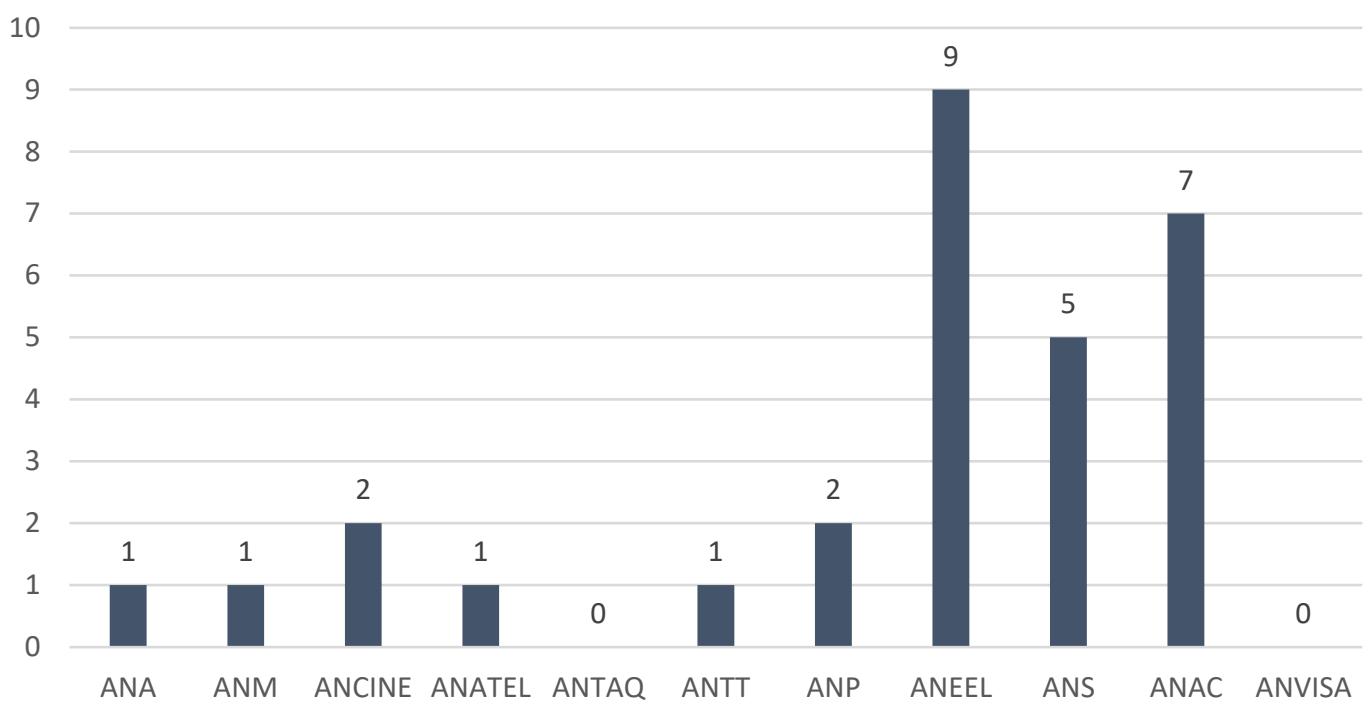

Source: Elaborated by the authors

The National Electricity Regulatory Agency (Agência Nacional de Energia Elétrica [ANEEL]) issued Order No 986 (2020) authorizing the Chamber of Electric Energy Commercialization (Câmara de Comercialização de Energia Elétrica [CCEE]) to transfer reserve fund resources to energy distributers which are part of the National Interconnected System (Sistema Interligado Nacional [SIN]), as well as free market agents. The agency estimates $\mathrm{R} \$ 2,022$ billion in transfers to these actors. The agency also took measures to alleviate $\mathrm{R} \$ 114$ million in financial burdens of electricity distributers and free consumers.

ANAC (2020) postponed collections from airport operators, a measure that had been previously authorized by Provisional Presidential Measure No 925 (2020). The agency also reached an agreement with airlines and other government institutions to establish new rules for flight rescheduling, flight cancellations, and ticket reimbursements. This agreement limited the rights of each consumer to one free rescheduling or cancellation. It also exempted airlines from assisting passengers with food and accommodation when they were not directly responsible for flight delays and cancellations. This agreement also prohibited the Consumer's National Department (Secretaria Nacional do Consumidor [SENACON]) to impose financial sanctions on airlines for a period of 180 days.

The National Agency of Supplementary Health (Agência Nacional de Saúde Suplementar [ANS]) relaxed a number of prudential rules ${ }^{10}$ in order to alleviate the financial burdens of health insurance companies. The agency allowed health insurance companies to use resources from reserve funds -

${ }^{10}$ Prudential rules require health insurance companies to maintain reserve funds to cover risky operations. These funds cannot be used by health care agencies unless ANS authorizes it. 
estimated in $\mathrm{R} \$ 1,7$ billion - to pay health service providers and to avoid contract terminations with delinquent consumers.

ANP extended contracts with oil and gas companies for a period of 9 months (Resolution No 815, 2020). Resolution No 816 (2020) relaxed contractual obligations of oil and gas producers, which included postponing their obligation for investing in research, development and innovation.

The committee in charge of managing the Audiovisual Sector Fund (Fundo Setorial Audiovisual [FSA]), which is part of the administrative structure of the National Film Agency (Agência Nacional do Cinema [ANCINE], approved emergency measures to support the audiovisual sector, which included the creation of a financial support program to small exhibitors and the approval of a special credit line to the audiovisual sector managed by the Brazilian Bank of Economic and Social Development (Banco Nacional de Desenvolvimento Econômico e Social [BNDES]). This committee also suspended payments to audiovisual companies with active credit operations at BNDES (ANCINE, 2020).

ANTT postponed tax collections from road infrastructure operators (Resolution No 5,892, 2020). ANM adopted measures to reduce bureaucracy in the mining sector and ANATEL temporarily suspended fine collection enforcement to regulated agents.

Finally, ANA temporarily suspended charges for water use in national rivers (Resolution No $18,2020)$ as a way to alleviate financial burdens of industries, farmers, as well as irrigation and sewage treatment companies.

\subsubsection{Protection to economically vulnerable consumers}

Lastly, a smaller number of agencies have also adopted measures to ensure that services would continue to be provided to economically vulnerable consumers. Graph 9 presents the number of protective measures adopted by each agency. 


\section{GRAPH 9 PROTECTION TO SERVICE CUSTOMERS}

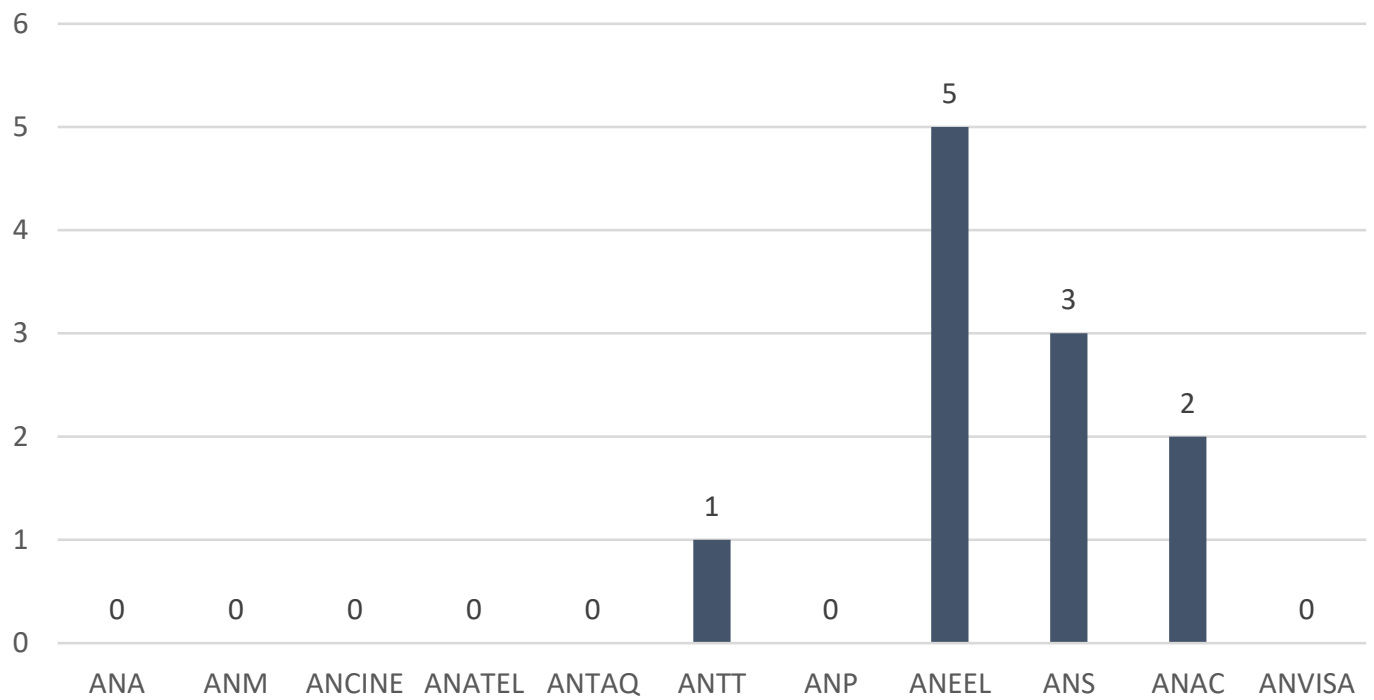

Source: Elaborated by the authors.

ANEEL issued Resolution No 878 (2020), which created rules to protect economically vulnerable consumers of electricity. This rule expressly forbade electricity companies to suspend energy supply to delinquent customers. This prohibition was applied to urban and rural residents, as well as clinics, hospitals, prisons, call center and funerary services.

Provisional Presidential Measure No 950 (2020) exempted low-income consumers from paying for electricity services if their consumption did not exceed $220 \mathrm{kWh} /$ month. Federal funds were transferred to electricity companies to cover these exemptions.

ANS, as mentioned, has relaxed a number of prudential rules to health service providers in exchange for not terminating contracts with consumers in debt. Health insurance companies had to sign an agreement with ANS in which they agreed to pay all health care providers and to facilitate payments to delinquent consumers in order to use reserve funds.

As already mentioned, ANAC signed an agreement with airlines in which the latter granted consumers the right to cancel or reschedule flights with no charges.

Unlike ANEEL, ANATEL and ANP did not adopt measures to protect economically vulnerable consumers who could not pay for telecommunications and gas services during the pandemic. A state court, however, prohibited the suspension of these services. The Judge of the 12th Federal Civil Court of São Paulo decided in the Public Civil Action No 500466232.2020.4.03.6100 that all service providers were prohibited from suspending telephone, gas and water supply services. However, this decision was reversed by the 3rd Regional Federal Court (Tribunal Regional Federal [TRF]), which restored to service providers the right to suspend services in case consumers don't pay for them. It should be noted that these decisions were also directed at water supply services which are regulated by state regulatory agencies not analyzed in this study. 


\section{LIMITS AND POSSIBILITIES OF REGULATORY RESPONSES}

The new coronavirus crisis requires effective, convenient and coordinated responses by regulatory agencies. Despite all the effort regulatory agencies put into responding to COVID-19, we identified problems in their behavior.

An analysis of agencies' measures by category allows us to draw evaluative comparisons. Graph 10 shows the percentage of actions fitted into each category, by agency, in a range from 0 to $1 .{ }^{11}$

\section{GRAPH 10 MEASURES IN RESPONSE TO COVID-19 BY CATEGORIES}

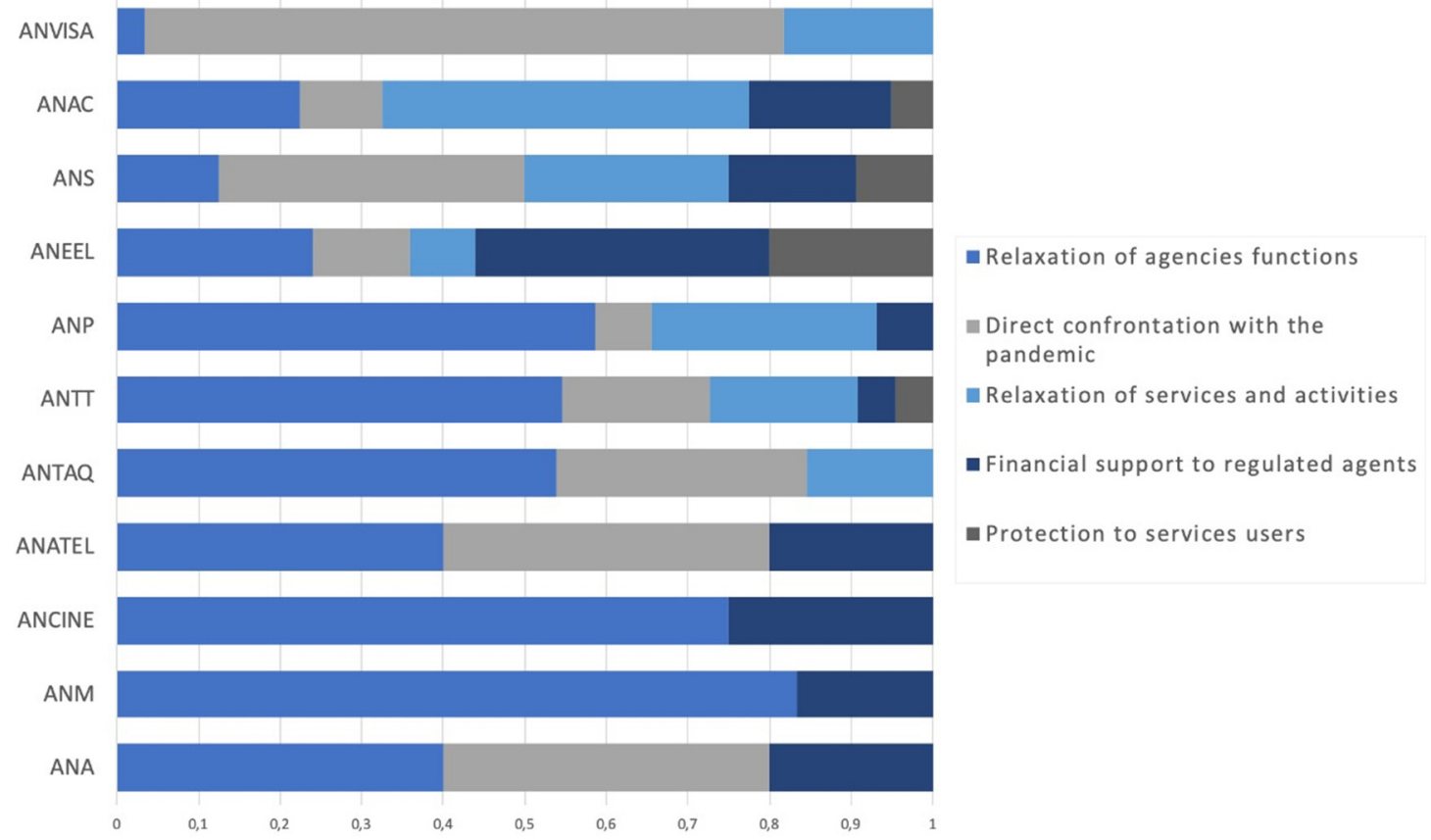

Source: Elaborated by the authors.

As previously mentioned, all federal regulatory agencies adopted measures in response to the COVID-19 pandemic. However, we verified considerable differences in these responses, which in part are caused by agencies' sectorial differences.

A relevant factor to the leading role played by ANVISA on facing COVID-19 is its regulatory scope. Sanitary control has relevant implications to almost all economic sectors. ANVISA's measures are used in the formation of legislative acts initiated by the Executive Power, as well in administrative rules issued by other agencies.

Unlike ANVISA, three agencies - ANA, ANCINE and ANM - offered only modest responses to the pandemic.

\footnotetext{
${ }^{11}$ The values were calculated based on the total number of actions adopted by each agency.
} 
A great deal of the measures analyzed in this study are not aimed at confronting COVID-19 directly. In several cases, coronavirus is presented as the background for measures that only respond to indirect effects of the pandemic, such as when agencies adopted actions to relax their own regulatory functions.

Although agencies regulate different sectors, they face similarities that require coordinated actions (Bradley, 2011; Marisam, 2011). There seems to exist coordination between ANVISA and transport agencies, especially ANAC, ANTT and ANTAQ. As mentioned before, sanitary surveillance measures determined by ANVISA are key to provide safety to passengers in ports, airports and railroads. Moreover, transport regulatory agencies play an important role in facilitating the transportation of infected passengers, pharmaceutical products, medicines and medical equipment.

ANAC, ANTT and ANTAQ regulate interstate transport of passengers. Although these agencies allowed transportation companies to reduce their route networks, they did not authorize the suspension of these services. Some state and local governments, however, issued orders banning intermunicipal and interstate transport in their territories. Although ANTT did not approve state and local government lock down measures, it faced limited authority to reverse their decisions. The Brazilian federative structure may trump some of these coordinating efforts (Schmidt, Mello, \& Cavalcante, 2020). In order to work, regulatory coordination must involve not only federal agencies but agencies from all levels of government.

Regulatory coordination instruments are important to solve asymmetry problems in responses offered by agencies. They are necessary to ensure regularity of service provision, to protect consumers and to support financially regulated agents. For example, agencies adopted measures to ensure that the provision of public services and key economic actions are not suspended during the crisis. We saw that measures to alleviate the financial burden of service providers and to protect economically vulnerable customers are key to ensure the regularity of service provision.

Nevertheless, agencies offered different responses to similar regulatory problems. Some of them adopted measures to protect economically vulnerable customers. ANEEL, besides granting $100 \%$ discount to low-income consumers, prohibited the suspension of electricity supply to delinquent consumers. ANS offered financial support to health insurance companies that accepted to renegotiate consumer's debts. ANATEL, ANP and several other state agencies of water supply, however, did not undertook similar measures. They resisted, even in courts, prohibiting suspension of services supply.

Given the sectorial differences of regulatory agencies' functions, it is understandable that they offer different responses to ensure regularity of service provision during the pandemic. Each regulatory agency must adopt its own measures to alleviate financial burdens of regulated agents, for example. But we think they should offer the same kinds of protections to users of utilities services of similar nature, such as electricity, mobile phone, internet, gas and water. It does not seem reasonable that one agency prohibits the suspension of one of these utility services to an economically vulnerable consumer, while another agency does not.

Agencies must resort to a wide range of regulatory coordination tools pointed out by the literature. Agreement terms, joint rules and mutual consultations between agencies are some of the possible tools to promote coordinated regulatory actions (Freeman \& Rossi, 2012; Kaiser, 2011). Regulatory 
RAP | Regulatory agencies in response to the COVID-19 crisis

coordination instruments are important to solve asymmetry problems in responses offered by agencies to ensure regularity of service provisions, protect consumers and alleviate the financial burdens of regulatory agents.

The Regulatory Agencies General Act (Statute No 13,848, 2019) established some coordination tools that may enable collaboration between agencies. However, agencies have not been resorting to these instruments when responding to the COVID-19 crisis.

Coordination between agencies needs to be strengthened so they can face the pandemic properly. We see here an opportunity for creating new instruments and implementing existing ones for promoting regulatory coordination. 


\section{REFERENCES}

Agência Nacional de Aviação Civil. (2020, April 22).

Demanda doméstica por voos cai 32,9\% em março, após pandemia do novo coronavírus. Retrieved from https://www.anac.gov.br/noticias/2020/demandadomestica-por-voos-cai-32-9-em-marco-apospandemia-do-novo-coronavirus

Agência Nacional de Aviação Civil. (2020, May 12). Postergado o pagamento de outorgas dos aeroportos de Guarulhos, Viracopos e Brasília. Retrieved from https://www.anac.gov.br/noticias/2020/postergadoo-pagamento-de-outorgas-dos-aeroportos-deguarulhos-viracopos-e-brasilia

Agência Nacional de Energia Elétrica. (2020, June 08). Em teletrabalho, Aneel economiza $R \$ 15$ milhões dos cofres públicos e aumenta produtividade. Retrieved from bit.ly/2ziATnS

Agência Nacional de Vigilância Sanitária. (2020, May 07). Nota da Anvisa sobre o PL 864/20. Retrieved from http://portal.anvisa.gov.br/web/ guest/noticias/-/asset_publisher/FXrpx9qY7FbU/ content/nota-da-anvisa-sobre-o-pl-86420/219201\#: :text=No\%20contexto $\% 20$ da $\% 20$ aprova $\% \mathrm{C} 3 \% \mathrm{~A} 7 \% \mathrm{C} 3 \% \mathrm{~A} 3 \mathrm{o} \% 20 \mathrm{do}$,esclarece $\% 20$ o\%20que $\% 20$ se $\% 20$ segue $\% 3$ A \& text $=$ A $\% 20$ regula \% C $3 \%$ A 7 \% C $3 \%$ A 3 o \% 20 d a $\% 20$ Anvisa\%20\%C3\%A9,\%2Dmercado\%20e\%20 p\%C3\%B3s\%2Dmercado

Agência Nacional do Cinema. (2020, June 25). Comitê Gestor do FSA aprova medidas de amparo ao setor audiovisual. Retrieved from https://www. ancine.gov.br/pt-br/sala-imprensa/noticias/comitgestor-do-fsa-aprova-medidas-de-amparo-ao-setoraudiovisual

Alves, R. (2020, June 09). ANA aumenta ritmo de regularização de usos de águas da União em 2020. Agência Nacional de Águas e Saneamento Básico. Retrieved from https://www.ana.gov.br/noticias/ ana-aumenta-ritmo-de-regularizacao-de-usos-deaguas-da-uniao-em-2020

Baldwin, R., Cave, M., \& Lodge, M. (2012). Understanding regulation: theory, strategy and practice (2a ed.). Oxford, UK: Oxford University Press.

Bradley, K. (2011). The Design of Agency Interactions. Columbia Law Review, 111(4), 745-794.
Coglianese, C., \& Walters, D. E. (2016). Agendasetting in the regulatory state: theory and evidence. Administrative Law Review, 68(1), 93-118.

Croda, J. H. R., \& Garcia, L. P. Resposta imediata da Vigilância em Saúde à epidemia da Covid-19. Epidemiologia e Serviços de Saúde, 29(1), 1-3.

Decisão no 83, de 20 de abril de 2020. (2020). Autoriza, em caráter excepcional e temporário, alterações de aeronaves e transporte de passageiros usando dispositivos de isolamento de pacientes (Patient Isolation Device [PID]). Brasília, DF: Diário Oficial da União.

Despacho no 986, de 7 de abril de 2020. (2020). Brasília, DF: Diário Oficial da União.

Decreto $n^{\circ} 10.139$, de 28 de novembro de 2019. (2019). Dispõe sobre a revisão e a consolidação dos atos normativos inferiores a decreto. Brasília, DF: Diário Oficial da União. Retrieved from http:// www.planalto.gov.br/ccivil_03/_ato2019-2022/2019/ decreto/D10139.htm

Freeman J., \& Rossi, J. (2012). Agency Coordination in Shared Regulatory Space. Harvard Law Review, 125(2), 131-1211.

Kaiser, F. M. (2011). Interagency collaborative agreements and activities: types, rationales, considerations (CFS Report for Congress R 41803). Washington, DC: US Congress.

Kerwin, C., \& Furlong, S. R. (2018). Rulemaking: how government agencies write law and make policy (5 ed.). London, UK: Sage Publications.

Lei n. 8.987, de 13 de fevereiro de 2015. (2015). Dispõe sobre o regime de concessão e permissão da prestação de serviços públicos previsto no art. 175 da Constituição Federal, e dá outras providências. Brasília, DF: Diário Oficial da União.

Lei n. 13.848 de 25 de junho de 2019. (2019). Dispõe sobre a gestão, a organização, o processo decisório e o controle social das agências reguladoras, altera a Lei ${ }^{\circ} 9.427$, de 26 de dezembro de 1996, a Lei $n^{\circ}$ 9.472, de 16 de julho de 1997, a Lei no 9.478, de 6 de agosto de 1997, a Lei n ${ }^{\circ} 9.782$, de 26 de janeiro de 1999, a Lei no 9.961, de 28 de janeiro de 2000, a Lei no 9.984, de 17 de julho de 2000, a Lei no 9.986, de 18 de julho de 2000, a Lei no 10.233 , de 5 de junho de 2001, a Medida Provisória no 2.228-1, de 6 de setembro de 2001, a Lei no 11.182 , de 27 de setembro de 2005, e a 
Lei no 10.180 , de 6 de fevereiro de 2001. Brasília, DF: Diário Oficial da União. Retrieved from http://www. planalto.gov.br/ccivil_03/_Ato2019-2022/2019/Lei/ L13848.htm

Lei $n$. 13.874, de 20 de setembro de 2019. (2019). Institui a Declaração de Direitos de Liberdade Econômica; estabelece garantias de livre mercado. Brasília, DF: Diário Oficial da União. Retrieved from http://www.planalto.gov.br/ccivil_03/_ato20192022/2019/lei/L13874.htm

Lei n. 13.989, de 15 de abril de 2020. (2020). Dispõe sobre o uso da telemedicina durante a crise causada pelo coronavírus (Sars-CoV-2). Brasília, DF: Diário Oficial da União. Retrieved from http://www. planalto.gov.br/ccivil_03/_Ato2019-2022/2020/Lei/ L13989.htm

Lodge, M. (2014). Regulatory capacity. In M. Lodge, \& K Wegrich (Eds.), The problem-solving capacity of the modern state. Oxford, UK: Oxford University Press.

Marisam, J. (2011). Duplicative Delegations. Administrative Law Review, 63(2), 181-244.

Marques, F. A., Neto. (2003). Agências Reguladoras: instrumentos do fortalecimento do Estado. Brasília, DF: Associação Brasileira de Agências de Regulação. Retrieved from http://abar.org.br/ mdocs-posts/agencias-reguladoras-instrumentosdo-fortalecimento-do-estado/

Matthews, F. (2012). Governance, governing and the capacity of executives in times of crisis. In M. Lodge, \& K Wegrich (Eds.), Executive Politics in Time of Crisis. Basingstoke, UK: Palgrave Macmillan.

Medida provisória no 925, de 18 de março de 2020. (2020). Dispõe sobre medidas emergenciais para a aviação civil brasileira em razão da pandemia da covid-19. Brasília, DF: Diário Oficial da União. Retrieved from http://www.planalto.gov.br/ ccivil_03/_ato2019-2022/2020/Mpv/mpv925.htm

Medida provisória no 950, de 8 de abril de 2020. (2020). Dispõe sobre medidas temporárias emergenciais destinadas ao setor elétrico para enfrentamento do estado de calamidade pública reconhecido pelo Decreto Legislativo $\mathrm{n}^{\circ} 6$, de 20 de março de 2020, e da emergência de saúde pública de importância internacional decorrente da pandemia de coronavírus (covid-19). Brasília, DF: Diário
Oficial da União. Retrieved from http://www.in.gov. br/en/web/dou/-/medida-provisoria-n-950-de-8de-abril-de-2020-251768271.

Organização para a Cooperação e o Desenvolvimento Econômico. (2020). Evaluating the initial impact of Covid-19 containment measures on economic activity. Paris, France: OCDE Publishing.

Organização para a Cooperação e o Desenvolvimento Econômico. (2020). A systemic resilience approach to dealing with Covid-19 and future shocks. Paris, France: OCDE Publishing.

Pereira, P. O. (2014). Análise da atuação internacional da Anvisa na perspectiva de seu corpo técnico e gerencial. Rio de Janeiro, RJ: Escola Nacional de Saúde Pública Sergio Arouca.

Portaria no 47, de 26 de março de 2020. (2020). Dispõe sobre a restrição excepcional e temporária de entrada no País de estrangeiros por transporte aquaviário, conforme recomendação da Agência Nacional de Vigilância Sanitária (Anvisa). Brasília, DF: Diário Oficial da União.

Portaria $n^{\circ} 74$, de 27 de janeiro de 2020. (2020). Dispõe sobre a criação de Grupo de Emergência em Saúde Pública para condução das ações referentes ao Novo Coronavírus (NCoV). Brasília, DF: Diário Oficial da União.

Portaria $n^{\circ}$ 102, de 12 de maio de 2020. (2020). Brasília, DF: Diário Oficial da União.

Portaria $n^{\circ}$ 109, de 18 de maio de 2020. (2020). Prorroga os prazos de medidas de combate à Covid-19. Brasília, DF: Diário Oficial da União.

Portaria $n^{\circ}$ 117, de 25 de março de 2020. (2020). Brasília, DF: Diário Oficial da União.

Portaria $n^{\circ} 125$, de 19 de março de 2020. (2020). Brasília, DF: Diário Oficial da União.

Portaria $n^{\circ}$ 134, de 28 de março de 2020. (2020). Brasília, DF: Diário Oficial da União.

Portaria $n^{\circ}$ 152, de 27 de março de 2020 (2020). Dispõe sobre a restrição excepcional e temporária de entrada no País de estrangeiros, conforme recomendação da Agência Nacional de Vigilância Sanitária (Anvisa). Brasília, DF: Diário Oficial da União. 
Portaria $n^{\circ} 157-e$. Altera a Portaria Ancine $n^{\circ} 151-$ E, de 19 de março de 2020. (2020). Estabelece, em caráter excepcional, medidas administrativas para a mitigação dos impactos do Covid-19 no setor audiovisual e no que se refere às atribuições da Agência Nacional do Cinema (Ancine), nos limites de sua competência. Brasília, DF: Diário Oficial da União.

Portaria $n^{\circ}$ 165, de 9 de junho de 2020. (2020). Institui o Comitê Gestor Monitoramento Covid Esgotos. Brasília, DF: Diário Oficial da União.

Portaria $n^{\circ}$ 467, de 20 de março de 2020. (2020). Dispõe, em caráter excepcional e temporário, sobre as ações de telemedicina, com o objetivo de regulamentar e operacionalizar as medidas de enfrentamento da emergência de saúde pública de importância internacional previstas no art. $3^{\circ} \mathrm{da}$ Lei $\mathrm{n}^{\circ} 13.979$, de 6 de fevereiro de 2020, decorrente da epidemia de Covid-19. Brasília, DF: Diário Oficial da União.

Portaria $n^{\circ}$ 880/SPO, de 27 de março de 2020. (2020). Autoriza transporte de carga por operador certificado sob o RBAC n 135 . Brasília, DF: Diário Oficial da União.

Portaria $n^{\circ} 1.153$, de 19 de março de 2020. (2020). Cria o Comitê de Crise para Supervisão e Monitoramento dos Impactos da Covid-19 no âmbito das Comunicações (Rede conectada MCTIC) e estabelece diretrizes a serem adotadas pela Agência Nacional de Telecomunicações (Anatel). Brasília, DF: Diário Oficial da União.

Portaria $n^{\circ}$ 6.310, de 24 de março de 2020. (2020). Brasília, DF: Diário Oficial da União.

Resolução CFM no 1.643/2002. (2002). Define e disciplina a prestação de serviços através da Telemedicina. Brasília, DF: Conselho Federal de Medicina. Retrieved from https://sistemas.cfm.org. br/normas/visualizar/resolucoes/BR/2002/1643

Resolução no 18, de 15 de abril 2020. (2020). Brasília, DF: Diário Oficial da União.

Resolução no 21, de 20 de abril de 2020. (2020). Dispõe sobre a prorrogação dos prazos de condicionantes e vigências de outorgas de uso de recursos hídricos, como medida emergencial de enfrentamento dos efeitos causados pela pandemia de Covid-19. Brasília, DF: Diário Oficial da União.
Resolução $n^{\circ}$ 347, de 12 de março de 2020. (2020). Define os critérios e os procedimentos extraordinários e temporários para a exposição à venda de preparações antissépticas ou sanitizantes oficinais, em virtude da emergência de saúde pública internacional relacionada ao Sars-CoV-2. Brasília, DF: Diário Oficial da União.

Resolução no 350, de 19 de março de 2020. (2020). Define os critérios e os procedimentos extraordinários e temporários para a fabricação e comercialização de preparações antissépticas ou sanitizantes oficinais sem prévia autorização da Anvisa e dá outras providências, em virtude da emergência de saúde pública internacional relacionada ao Sars-CoV-2. Brasília, DF: Diário Oficial da União.

Resolução no 355, de 23 de março de 2020. (2020). Dispõe sobre a suspensão dos prazos processuais afetos aos requerimentos de atos públicos de liberação de responsabilidade da Anvisa em virtude da emergência de saúde pública internacional relacionada ao Sars-CoV-2. Brasília, DF: Diário Oficial da União.

Resolução no 356, de 23 de março de 2020. (2020). Dispõe, de forma extraordinária e temporária, sobre os requisitos para a fabricação, importação e aquisição de dispositivos médicos identificados como prioritários para uso em serviços de saúde, em virtude da emergência de saúde pública internacional relacionada ao Sars-CoV-2. Brasília, DF: Diário Oficial da União.

Resolução no 364, de 01 de abril de 2020. (2020). Suspende os efeitos da Resolução de Diretoria Colegiada (RDC) no 302, de 13 de outubro de 2005, em caráter temporário e excepcional, para os Laboratórios Federais de Defesa Agropecuária (LFDA) que irão realizar análises para o diagnóstico da Covid-19. Brasília, DF: Diário Oficial da União.

Resolução no 556, de 13 de maio de 2020. (2020). Flexibiliza em caráter excepcional e temporário da aplicação de dispositivos da Resolução no 400, de 13 de dezembro de 2016, em decorrência dos efeitos da pandemia da Covid-19. Brasília, DF: Diário Oficial da União.

Resolução no 812, de 23 de março de 2020. (2020). Define procedimentos a serem adotados pelos agentes regulados pela ANP, enquanto durarem as medidas temporárias de enfrentamento da 
emergência de saúde pública de importância internacional decorrente do Coronavírus (Covid-19) estabelecidas por estados e municípios da federação. Brasília, DF: Diário Oficial da União.

Resolução $n^{\circ}$ 815, de 20 de abril de 2020. (2020). Faculta a prorrogação de prazos relativos aos contratos de exploração e produção de petróleo e gás natural. Brasília, DF: Diário Oficial da União.

Resolução $n^{\circ}$ 816, de 20 de abril de 2020. (2020). Define procedimentos a serem adotados pelos agentes regulados pela ANP que atuam nas atividades de exploração e produção de petróleo e gás natural, enquanto perdurarem as medidas temporárias de enfrentamento da emergência de saúde pública de importância internacional decorrente do Coronavírus (Covid-19) estabelecidas pelo governo federal. Brasília, DF: Diário Oficial da União.

Resolução no 5.875, de 17 de março de 2020. (2020). Dispõe sobre as medidas para enfrentamento da emergência de saúde pública de importância internacional decorrente do coronavírus responsável pelo surto de 2019/2020, no âmbito do serviço de transporte rodoviário interestadual e internacional de passageiros. Brasília, DF: Diário Oficial da União.

Resolução no 5.878, de 26 de março de 2020. (2020). Suspende os prazos processuais no âmbito dos processos administrativos sancionadores de que trata a resolução ${ }^{\circ} 5.083$, de 27 de abril de 2016. Brasília, DF: Diário Oficial da União.

Resolução $n^{\circ}$ 5.879, de 26 de março de 2020. (2020). Dispõe sobre a flexibilização de prazos para cumprimento de obrigações contratuais e regulatórias, em razão da emergência de saúde pública de importância internacional decorrente do coronavírus, no âmbito da infraestrutura e serviço de transporte ferroviário de cargas e do transporte rodoviário de cargas e de passageiros, e dá outras providências. Brasília, DF: Diário Oficial da União.

Resolução no 5.891, de 26 de maio de 2020. (2020). Dispõe sobre a substituição das sessões presenciais de Reuniões Participativas ou Audiências Públicas por sessões públicas transmitidas por meio de videoconferência ou outro meio eletrônico, em razão do estado de emergência de saúde pública de importância internacional decorrente da pandemia da Covid-19. Brasília, DF: Diário Oficial da União.
Resolução $n^{\circ} 7.653$, de 31 de março de 2020. (2020). Revisa e consolida as medidas em resposta à emergência de saúde pública no âmbito do transporte aquaviário e das instalações portuárias em razão da epidemia do coronavírus (Covid-19). Brasília, DF: Diário Oficial da União.

Resolução $n^{\circ} 7.784$, de 5 de junho de 2020. (2020). Suspende os prazos pontualmente previstos na resolução normativa no $^{\circ} 32 / 2019$, na resolução normativa no $29 / 2019$, na resolução normativa ${ }^{\circ}$ 28/2019 e na resolução $n^{\circ} 3.274 / 2014$, bem como aqueles relacionados à contabilidade regulatória das administrações portuárias. Brasília, DF: Diário Oficial da União.

Resolução normativa $n^{\circ}$ 259, de 17 de junho de 2011. (2011). Dispõe sobre a garantia de atendimento dos beneficiários de plano privado de assistência à saúde e altera a Instrução Normativa no 23 , de $1^{\circ}$ de dezembro de 2009, da Diretoria de Normas e Habilitação dos Produtos. Brasília, DF: Diário Oficial da União.

Resolução normativa $n^{\circ} 453$, de 12 de março de 2020. (2020). Altera a Resolução Normativa no 428, de 7 de novembro de 2020, que dispõe sobre o Rol de Procedimentos e Eventos em Saúde no âmbito da Saúde Suplementar, para regulamentar a cobertura obrigatória e a utilização de testes diagnósticos para infecção pelo Coronavírus. Brasília, DF: Diário Oficial da União.

Resolução normativa no 458, de 26 de junho de 2020. (2020). Altera a Resolução Normativa no 428 , de 7 de novembro de 2017, que dispõe sobre o Rol de Procedimentos e Eventos em Saúde no âmbito da Saúde Suplementar, para regulamentar a cobertura obrigatória e a utilização de testes sorológicos para a infecção pelo coronavírus (Covid-19), em cumprimento a determinação judicial proferida nos autos da Ação Civil Pública no 0810140 15.2020.4.05.8300. Brasília, DF: Diário Oficial da União.

Resolução normativa no 878, de 24 de março de 2020. (2020). Medidas para preservação da prestação do serviço público de distribuição de energia elétrica em decorrência da calamidade pública atinente à pandemia de coronavírus (Covid-19). Brasília, DF: Diário Oficial da União. 
Resolução-RE no 922, de 27 de março de 2020. (2020). Brasília, DF: Diário Oficial da União.

Salinas, N. S. C., \& Brelaz, G. (2020). Limites da AIR como Instrumento de Promoção da Liberdade Econômica. In A. J. C. Cunha, Filho, R. R. Picelli,
\& R. M. Maciel (Orgs.), Lei de liberdade econômica anotada. São Paulo, SP: Quartier Latin.

Schmidt, F., Mello, J., \& Cavalcante P. (2020). Estratégias de coordenação governamental na crise da Covid-19. Brasília, DF: Ipea.

\section{Sérgio Guerra}

http://orcid.org/0000-0002-2373-7369

Dean of Rio de Janeiro School of Law at Fundação Getulio Vargas (FGV DIREITO RIO); Administrative Law Professor at the Graduate Program on Law \& Regulation (Masters and Doctorate) at the Rio de Janeiro School of Law at Fundação Getulio Vargas (FGV DIREITO RIO); Holds a Ph.D. and a Master's Degree in Law; Visiting Researcher at Yale Law School; Editor-in-chief of the Revista de Direito Administrativo (RDA); Coordinator of the International Business Law Course at the University of California - Irvine; Ambassador of Yale University in Brazil; Legal advisor of the Public Law Commission at the Bar Association of Rio de Janeiro State (OAB/ RJ). E-mail: sergio.guerra@fgv.br

\section{Natasha Schmitt Caccia Salinas}

http://orcid.org/0000-0003-1012-1132

Professor at the Graduate Program on Law \& Regulation and the undergraduate program at Rio de Janeiro School of Law School at Fundação Getulio Vargas (FGV DIREITO RIO); Holds a Ph.D. and a Master's Degree in Law from the University of São Paulo (USP), and the title of Master of Laws (LL.M.) from Yale Law School. E-mail: natasha.salinas@fgv.br

\section{Lucas Thevenard Gomes}

https://orcid.org/0000-0001-5011-4960

Researcher at the Center for Research in Law \& Economics (Centro de Pesquisas em Direito e Economia [CPDE]) at the Rio de Janeiro Law School at Fundação Getulio Vargas (FGV DIREITO RIO); Holds a graduate degree in Foreign Affairs from Fundação Getulio Vargas and a Bachelor's Degree in Law from Rio de Janeiro Law School at Fundação Getulio Vargas (FGV). E-mail: lucas.gomes@fgv.br 